\title{
Intracranial Artery
}

National Cancer Institute

\section{Source}

National Cancer Institute. Intracranial Artery. NCI Thesaurus. Code C12980.

Arteries which have their origins within the intracranial cavity. 